\title{
A novel and efficient synthesis of selenides
}

\author{
He M. Lin, Yu Tang,* Zhi H. Li, Kun D. Liu, Jun Yang, and Yuan M. Zhang \\ Department of Chemistry, Jinan University, Guangzhou, Guangdong 510 632, China \\ E-mail: tytang@jnu.edu.cn
}

\begin{abstract}
Under nitrogen atmosphere, a simple and efficient procedure for the synthesis of symmetrical selenides has been developed by the reaction of aryl or alkyl halides with magnesium (1.5 equiv) and elemental selenium (1.0 equiv) in the absence of catalyst and ligand in THF and toluene under reflux at $86^{\circ} \mathrm{C}$. This protocol has been utilized for the synthesis of a variety of symmetrical selenides in good to excellent yields.
\end{abstract}

Keywords: Symmetrical selenides, aryl or alkyl halides, magnesium, elemental selenium

\section{Introduction}

Organoselenium chemistry has been the subject of constant scientific interest over the past 30 years, and now is a very useful tool in the hands of synthetic chemists. ${ }^{1}$ Organic selenides are key intermediates in organic synthesis as well as in medicine. ${ }^{2}$ Two most important classes of organoselenium compound are selenides and diselenides. ${ }^{3}$ They have antioxidant, apoptosis, antiviral and antitumor properties. ${ }^{4}$ Hence there are many papers reporting methods for the preparation of selenides. The selenium ion always formed from element selenium reaction with reductants such as $\mathrm{NaBH}_{4},{ }^{5} \mathrm{NaH}^{6}{ }^{6} \mathrm{Na},{ }^{7}$ or organic lithium, was used to prepare selenides. This route is limited to produce symmetrical alkyl selenides, but not suitable for inactive or electron rich aryl halides. Also these traditional reactions require harsh reaction conditions such as the use of polar and toxic solvents like HMPA or NMP, high reaction temperatures, long reaction times, and always result in low yields. Recently, an effective method to synthesize unsymmetrical selenides has been reported through the reaction of organic halides with the product of diselenide reduction. ${ }^{8}$ Catalysts like indium, ${ }^{9}$ copper, ${ }^{10}$ palladium or tin, ${ }^{11}$ nickel, ${ }^{12}$ ruthenium ${ }^{13}$ and $\mathrm{CuS} / \mathrm{Fe}^{14}$ are often applied, but the starting diselenides should be prepared. Deoxygenation of selenoxides, selenones with $\mathrm{Mg}-\mathrm{MeOH}$ to synthesize selenides has also been reported. ${ }^{15}$ However the reaction needs a large excess of magnesium (20:1) as the starting material and long reaction time. In the latest reports of symmetrical diaryl selenide synthesis, selenourea ${ }^{16}$ or selenocyanate ${ }^{17}$ was used, but only the active and expensive aryl iodides could afford products in 
high yields after a long reaction time. Here, we report the efficient synthesis of symmetrical selenides by a novel method. We find that aryl and alkyl bromides react with magnesium and elemental selenium in THF-toluene in the absence of catalyst and ligand to afford corresponding symmetrical selenides in high yield.

\section{Results and Discussion}

As shown in Scheme 1, $\mathrm{PhSeMgBr}$ could be formed by reacting selenium with phenyl Grignard reagent. Then, $\mathrm{PhSeMgBr}$ reacted with phenyl bromide to give diphenyl selenide in the absence of catalyst and ligand.

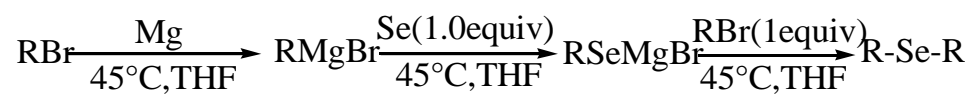

Scheme 1. Synthesis of selenide via magnesium selenolate.

Diphenyl selenide was afforded in $12 \%$ yield (Table 1, entry 1) by employing equivalent amount of magnesium to selenium. In order to improve the yield, excess magnesium was firstly employed to shift the equilibrium of $\mathrm{PhMgBr}$ formation. Surprisingly, yield of diphenyl selenide was increased to $26 \%$ (Table 1 , entry 2 ) by using 2 equivalent mount of magnesium. Thus, triple amount of magnesium was employed, which resulted in large enhancement yield to $45 \%$ of diphenyl selenide (Table 1, entry 3). 4 times amount of magnesium only give $43 \%$ yield (Table 1 , entry 4), which indicated triple amount of magnesium was enough to improve the reaction.

Table 1. Effects of magnesium amount on the yield of $\mathrm{PhSePh} 1$

$$
\mathrm{PhBr} \underset{45^{\circ} \mathrm{C}, \mathrm{THF}}{\stackrel{\mathrm{Mg}}{\longrightarrow}} \mathrm{PhMgBr} \underset{45^{\circ} \mathrm{C}, \mathrm{THF}}{\stackrel{\mathrm{Se}(1 \text { equiv })}{\longrightarrow}} \mathrm{PhSeMgBr} \underset{45^{\circ} \mathrm{C}, \mathrm{THF}}{\stackrel{\mathrm{PhBr}(1 \text { equiv })}{\longrightarrow}} \mathrm{PhSePh}
$$

\begin{tabular}{ccc}
\hline Entry & Mg (times) & ${\text { Yield }(\%)^{\mathrm{a}}}^{\mathrm{a}}$ \\
\hline 1 & 1 & 12 \\
2 & 2 & 26 \\
3 & 3 & 45 \\
4 & 4 & 43 \\
\hline
\end{tabular}

${ }^{\mathrm{a}} \mathrm{GC}$ yields based on selenium.

As double amount of magnesium could achieve equilibrium shift, the result obtained by employing triple amount of magnesium indicates some other effects of excess magnesium may exist in the reaction. The second part, bromobenzene, may react with excess magnesium and the left selenium from formation of magnesium phenylselenolate to give diphenyl selenide directly. 
Thus, without forming magnesium selenolate, reaction in Scheme 2 was carried out with bromoanisole instead of more volatile bromobenzene as model compound for convenient observation of starting material with TLC. Conditions such as quantity of selenium and magnesium, air or nitrogen atmosphere, various solvents, water in solvent, catalysts and ligands were discussed to optimize reaction (Table 2).

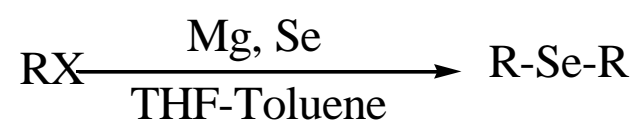

Scheme 2. Synthesis of symmetrical selenide without formation of magnesium selenolate.

Table 2. Screening of the optimum reacting condition for synthesis of selenides ${ }^{\mathrm{a}} \mathbf{2}$

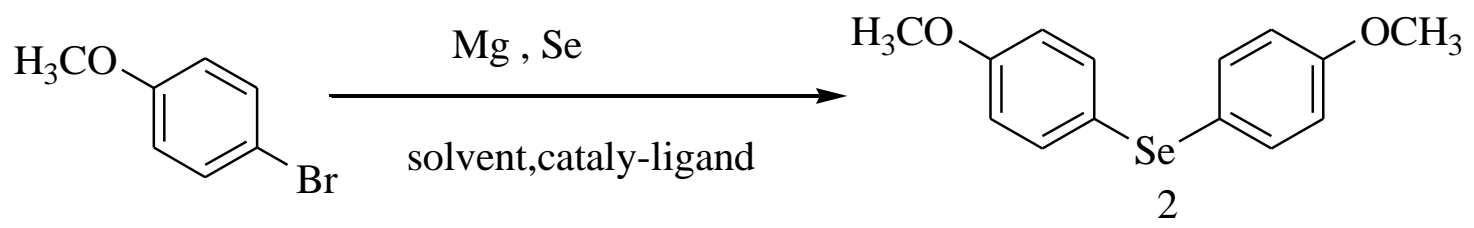

\begin{tabular}{|c|c|c|c|c|c|}
\hline Entry & $\operatorname{Mg}($ equiv $)$ & Solvent & $\mathrm{T}\left({ }^{\circ} \mathrm{C}\right)$ & Time (h) & yield $^{\mathrm{b}}(\%)$ \\
\hline 1 & 1.0 & $\mathrm{THF}^{\mathrm{c}}$ & reflux & 8 & $42^{d}$ \\
\hline 2 & 1.0 & $\mathrm{THF}^{\mathrm{c}}$ & reflux & 8 & 81 \\
\hline 3 & 1.0 & $\mathrm{THF}$ & reflux & 8 & 80 \\
\hline 4 & 1.3 & $\mathrm{THF}$ & reflux & 6.5 & 90 \\
\hline 5 & 1.5 & THF & reflux & 3 & 96 \\
\hline 6 & 2.0 & THF & reflux & 3 & 95 \\
\hline 7 & 1.5 & THF-toluene & reflux & 1.5 & 98 \\
\hline 8 & 1.5 & Toluene & 105 & 24 & trace \\
\hline 9 & 1.5 & THF-DMSO & 110 & 24 & 37 \\
\hline 10 & 1.5 & THF-DMF & 110 & 24 & 26 \\
\hline 11 & 1.5 & THF-dioxane & 95 & 24 & trace \\
\hline 12 & 1.5 & THF-toluene/ $0.1 \mathrm{ml} \mathrm{H}_{2} \mathrm{O}$ & reflux & 4.5 & 72 \\
\hline 13 & 1.5 & THF-toluene $/ 0.5 \mathrm{ml} \mathrm{H}{ }_{2} \mathrm{O}$ & reflux & 8.5 & 46 \\
\hline 14 & 1.5 & THF-toluene/1.0ml H $\mathrm{H}_{2} \mathrm{O}$ & reflux & 24 & trace \\
\hline
\end{tabular}

${ }^{a}$ Reaction conditions: bromo-anisole $(10.0 \mathrm{mmol})$, Se (1.0 equiv), catalyst $(7.5 \mathrm{~mol} \%)$. When the solvent is THF, the reflux temperature is $75{ }^{\circ} \mathrm{C}$. The solvent is THF-toluene, and the reflux temperature is $86{ }^{\circ} \mathrm{C} .{ }^{b}$ Isolated yield. ${ }^{c}$ Dry THF. ${ }^{d}$ Reaction under air atmosphere.

bis-(4-Methoxyphenyl) selenide was formed in $42 \%$ yield (Table 2, entry 1) by employing equivalent amounts of magnesium to selenium under air atmosphere. While the reaction was 
carried out under nitrogen atmosphere and other reaction conditions stayed the same, the yield reached $80 \%$ (Table 2, entry 2). In Scheme 1, the preparation of Grignard reagent should be performed in dry THF. To our surprise, the selenide synthesis in Scheme 2 resulted in $80 \%$ yield also in THF without anhydrous treatment (Table 2, entry 3 ). This makes the operation procedure more simple and convenient. Because 4-bromoanisole still left under equivalent amount of magnesium, excess magnesium was employed. The starting material decreased and disappeared under the conditions of 1.3 and 1.5 equivalent amount of magnesium, while the yield reached high to $90 \%$ and $96 \%$, respectively (Table 2, entries 4 and 5). Double amount of magnesium could not increase the yield any more (Table 2, entry 6). Thus, 1.5 equivalent amount of magnesium was used in the other reactions. Other solvents such as toluene, DMF, DMSO and dioxane were mixed with THF to carry out the reaction (Table 2, entries 7, 9, 10 and 11). Only THF-toluene could reduce the reaction time from 3 to $1.5 \mathrm{~h}$ and keep the excellent yield to $98 \%$.

The role of toluene is to accelerate the reaction by improving the reaction temperature to $86^{\circ} \mathrm{C}$, which could be supported by the trace yield of reaction in toluene (Table 2, entry 8 ). We also discuss the influence of catalysts and ligands on the reaction. Although the yields were among $90 \%$ to $96 \%$, the catalysts and ligands (e.g., CuI, CuBr, CuI- diethylamine, CuITMEDA) displayed bad effect on reaction by extending the reaction time to 18 to $24 \mathrm{~h}$. In order to understand the reaction mechanism, we tried to add some water to the reaction. The results indicated that the reaction time was prolonged and the yield decreased with the water amount increase (Table2, entries 12 14). As iodine could promote the formation of Grignard reagent, we also added small amount of iodine to the reaction. Although the yield is $95 \%$, reaction time was extended to $24 \mathrm{~h}$. Careful analysis of the optimized reactions revealed that the optimum conditions for this reaction were the use of excess magnesium (1.5 equiv), elemental selenium (1.0 equiv), aryl or alkyl halides (2.0 equiv), and THF-toluene as solvent under nitrogen atmosphere by heating the reaction mixture under reflux at $86^{\circ} \mathrm{C}$. Many aryl and alkyl halides were employed in the reaction to explore the scope and limitation of this methodology under the optimized conditions. Different kinds of symmetrical selenides were obtained in high yields (Table 3).

Upon analysis of Table 3, it could be verified that n-butyl bromide and 3-methoxypropyl bromide, the primary bromides, could produce corresponding selenides in excellent yields of $95 \%$ and $92 \%$, respectively (Table 3, entries 1 and 2). Other primary halides benzyl bromide and 4-methylbenzyl chloride gave high yields of $82 \%$ and $85 \%$, respectively (Table 3, entries 3 and 4). This result indicates no obvious effect of different bromo-, chloro- groups and methyl- on benzene on the reaction. 2-(Bromomethyl)-1,3-dioxolane resulted in a low yield of $42 \%$, which could be improved to $79 \%$ by adding 3 equivalents of magnesium (Table 3, entry 5 ). The effect of the acetal structure on magnesium may exist and consume some amount of magnesium, which could be supported by the similar yields obtained from t-butyl bromide, 1-phenylethyl bromide and 2,4-dimethylphenyl bromide by employing 3 equivalent amounts of magnesium compared with those of 1.5 equivalent amount of magnesium (Table 3, entries 7, 8 and 21). Cyclohexyl bromide, the secondary bromide, afforded the selenide in excellent yield of 92\% also (Table 3, 
entry 6). 1-Phenylethyl bromide and t-butyl bromide gave the corresponding products in yields of $71 \%$ and $43 \%$ respectively (Table 3 , entries 7 and 8 ), which contributes to the steric hindrance effect.

Table 3. Symmetrical selenides $\mathbf{3}$ synthesized from various halides

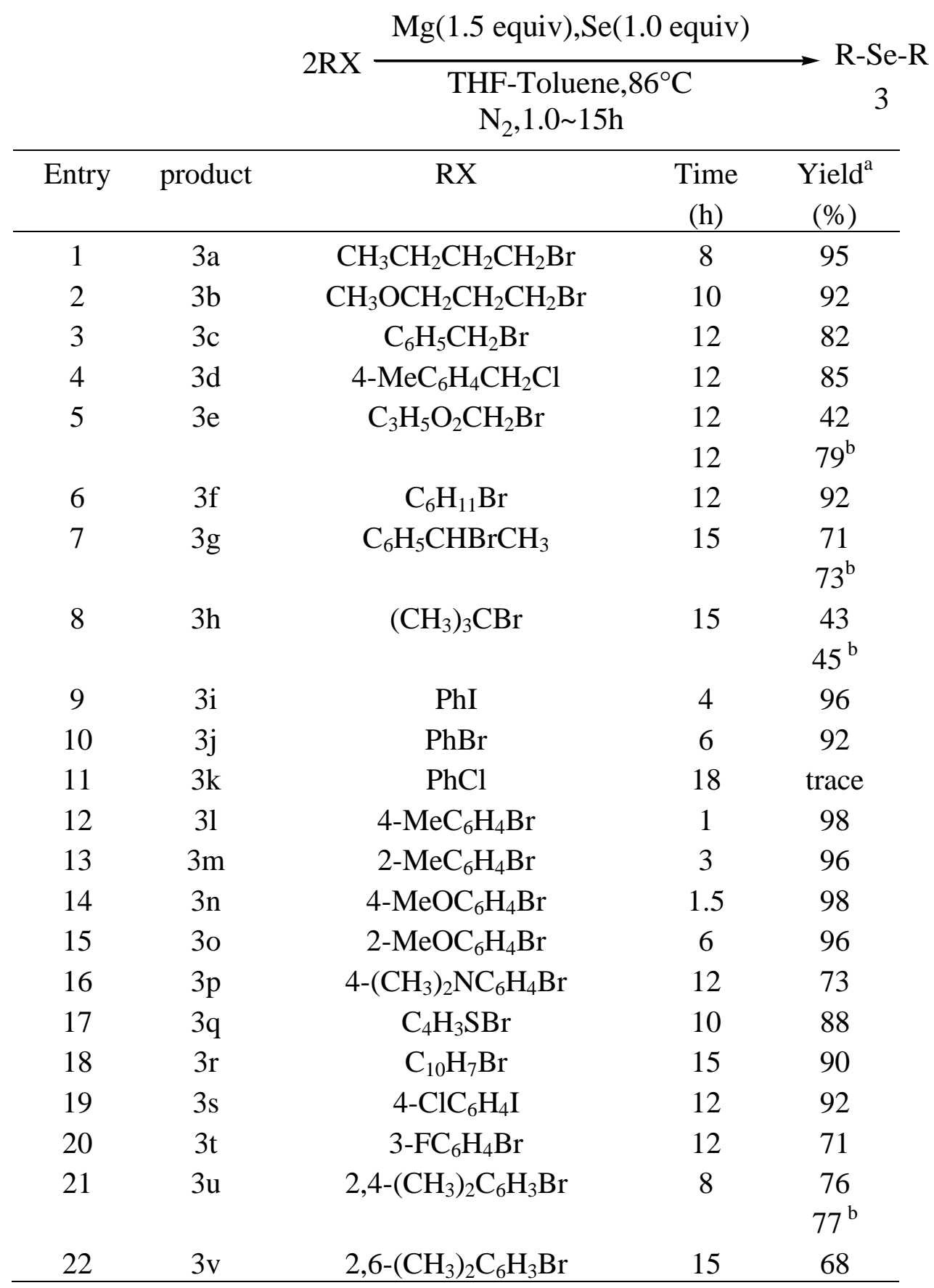

${ }^{\mathrm{a}}$ Isolated yield. ${ }^{\mathrm{b}} \mathrm{Mg}$ (3.0 equiv.). 
Phenyl iodide displayed more reactive substrate than phenyl bromide and chloride by yielding product in $96 \%$ after reacting for $4 \mathrm{~h}$ (Table 3, entry 9). Phenyl bromide could also afford excellent product yield of $92 \%$ after a longer reaction time of $6 \mathrm{~h}$, whereas trace amount of product was observed for aryl chloride (Table 3, entries 10 and 11). Phenyl bromides bearing electron-donating groups of $\mathrm{Me}$ - and $\mathrm{MeO}$ - could finish the reaction in shorter time than the other reactants to produce the corresponding selenides in excellent yields of 96-98\% (Table3, entries 12-15). The steric hindrance of $o$-bromotoluene and $o$-bromo-anisole displayed no effect on yield, but resulted in longer reaction times than their corresponding para- isomers (Table 3, entries 13 and 15). The other electron-donating group of $\left(\mathrm{CH}_{3}\right)_{2} \mathrm{~N}$ on 4-bromo-N,Ndimethylaniline caused lower yield of $73 \%$ and longer reaction time of $12 \mathrm{~h}$ (Table 3 , entry16) than that of phenyl bromide (Table 3, entry 10). The treatment of 2-bromothiophene and 1bromonaphthalene bromide gave the desired products in high yield of 88 and 90\% (Table 3, entries 17 and 18). In the presence of $\mathrm{CuO}$ nanoparticles, aryl iodides and bromides could react with seleno-urea to give symmetrical diaryl selenides. ${ }^{19}$ Although the reaction could reach yields of $84 \sim 98 \%$ by employing aryl iodides, aryl bromides could be converted to symmetrical selenides only in yields of $61 \sim 78 \%$. Such as, 4-bromotoluene yielded selenide in $76 \%$ after reacting for $20 \mathrm{~h}$, and bromobenzene yielded selenide in $61 \%$, but decreased to $25 \%$ when the catalyst was changed from $\mathrm{CuO}$ nanoparticles to $\mathrm{CuO}$. $\mathrm{C}-\mathrm{Se}$ cross coupling of potassium selenocyanate with aryl halides to synthesis symmetrical selenides was reported by using the catalyst system of $\mathrm{CuI}$ and ligand. ${ }^{20}$ In this paper, aryl iodides could afford symmetrical selenides in yields of 61 91\%, but aryl bromides gave symmetrical selenides in yields of $45 \sim 79 \%$, such as, the yield of bis-(2-thienyl) selenide could only reach $58 \%$ by using 2bromothiophene after reacting for $40 \mathrm{~h}$, and $79 \%$ even by using 2 -iodothiophene after reacting for $24 \mathrm{~h}$. Compared with these results in latest literatures, our method applied to synthesize symmetrical selenide is much better.

In the presence of electron withdrawing groups of $\mathrm{Cl}$ and $\mathrm{F}$, a slight decreasing yield of $92 \%$ for $p$-chlorophenyl iodide and obvious decreasing yield of $71 \%$ for $m$-fluorophenyl bromide (Table 3, entries 19 and 20) were observed compared with those for corresponding phenyl iodide and phenyl bromide (Table 3, entries 9 and 10). The yield of $76 \%$ for 2,4-dimethylbromobenzene is lower than those for $p$-bromotoluene and $o$-bromotoluene even after reacting for a longer time of $8 \mathrm{~h}$ (Table 3 , entries 21). It is hard to attribute to steric hindrance, and further works are needed. The yield of $68 \%$ for 2,6-dimethylbromobenzene indicate the higher influence of steric hindrance (Table 3, entry 22). For aryl bromide bearing with strong electron withdrawing group of nitro or active hydrogen group of amino, the reaction won't occur under the optimized conditions.

According to the experimental results, we propose a plausible pathway of symmetrical selenide formation, as shown in Figure 1. 


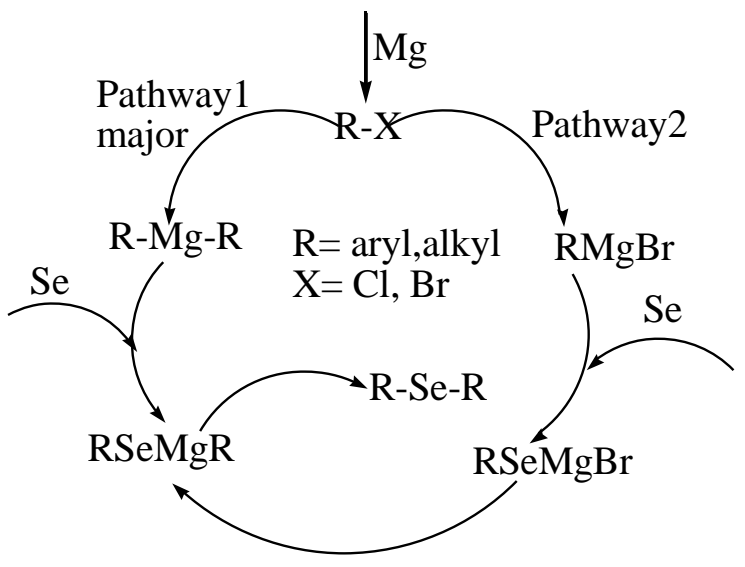

Figure1. Plausible pathways for symmetrical selenide synthesis.

There are two possible ways to produce symmetrical selenide. In pathway 1, aryl or alkyl halides could react with magnesium to give diaryl- or dialkyl- magnesium. Then, selenium inserts into diaryl- or dialkyl- magnesium to form RSeMgR. In pathway 2 , the aryl or alkyl halide reacts with magnesium to form Grignard reagent. Then, insertion of selenium into Grignard reagent leads to magnesium organoselenolate, which reacts with RX to give RSeMgR. Finally, RSeMgR eliminates magnesium to afford symmetrical selenide. We have carried out the reaction by pathway 2 as shown in Scheme 1 . But the result was bad. Thus, the pathway 1 is proposed the major process in the high efficient synthesis of symmetrical selenides. The formation of $\mathrm{RMgR}^{18}$ could be supported from the observation of product 4,4'dimethoxybiphenyl by reaction of 4-bromoanisole and magnesium without addition of selenium in THF without anhydrous treatment. The formation of $\mathrm{RMgR}$ from the reaction of aryl bromides and magnesium could explain why the reaction of Aryl bromides bearing nitro and amino groups could not occur, and THF without anhydrous treatment could be employed as solvent. Actually, the Grignard reagent in pathway 2 could only be prepared in anhydrous THF. The addition of $\mathrm{CuI}$ or $\mathrm{CuBr}$ would cause $\mathrm{Cu}^{+}$reacts with 4-bromoanisole to form corresponding metal compound. ${ }^{19}$ The insertion of selenium in this metal compound is possible slower than that in $\mathrm{RMgR}$, which causes longer reaction time (Table 2, entries 12-16).

\section{Conclusions}

In conclusion, we have developed an experimentally simple and efficient procedure to selenide synthesis without catalyst and ligand. This methodology is highly chemoselective, and allows the preparation of a wide range of substituted symmetrical selenides containing aryl, alkyl, heteroaryl or heteroalkyl in good to excellent yields. 


\section{Experimental Section}

General. ${ }^{1} \mathrm{H}$ - and ${ }^{13} \mathrm{C}$ - NMR spectra were recorded in $\mathrm{CDCl}_{3}$ on an AVANCE-300 spectrometer. Chemical shifts are reported in $\delta$ ppm referenced to an internal tetramethylsilane (TMS) standard .IR spectra were measured by an Eqinox 55 FT-IR spectrometer, from $4000 \mathrm{~cm}^{-1}$ to $400 \mathrm{~cm}^{-1}$. Gas chromatography/ mass spectra were measured on a Finnigan Trace GC/MS. Elemental analyses were performed on a Vario EL analyzer.

General experimental procedure for the synthesis of selenides. Magnesium chips (180 $\mathrm{mg}$, $7.5 \mathrm{mmol}$ ) were placed in a three-necked, $50 \mathrm{ml}$ flask equipped with a magnetic stirring bar, a reflux condenser and a nitrogen bubbling tube flushed with nitrogen. Then, THF (15ml) and toluene $(15 \mathrm{ml})$ were added as solvents, $\mathrm{RX}(10 \mathrm{mmol})$ and selenium powder $(0.4 \mathrm{~g}, 5 \mathrm{mmol})$ were added to the reacting mixture in batches. The reaction mixture was heated at $86{ }^{\circ} \mathrm{C}$ under a nitrogen atmosphere for $1.0-15 \mathrm{~h}$, the progress of the reaction was monitored by TLC. After completion of the reaction, the reaction mixture was extracted with ethyl acetate $(3 \times 8 \mathrm{ml})$. After the ethyl acetate was evaporated under reduced pressure, the crude product was analyzed by GC-MS directly. Pure product could be obtained by TLC with petroleum as developing solvent.

di-n-Butyl selenide (3a). ${ }^{15}$ Yellow oil, yield: $95 \%, 922 \mathrm{mg} ;{ }^{1} \mathrm{H}-\mathrm{NMR}\left(300 \mathrm{MHz}, \mathrm{CDCl}_{3}\right): \delta_{\mathrm{H}}$ $2.57\left(\mathrm{t}, J=7.5 \mathrm{~Hz}, 4 \mathrm{H}, \mathrm{SeCH}_{2}\right), 1.68-1.60\left(\mathrm{~m}, 4 \mathrm{H}, \mathrm{CH}_{2} \mathrm{CH}_{2}\right), 1.45-1.38\left(\mathrm{~m}, 4 \mathrm{H}, \mathrm{CH}_{2} \mathrm{CH}_{3}\right), 0.93$ (t, $\left.J=7.4 \mathrm{~Hz}, 6 \mathrm{H}, \mathrm{CH}_{3}\right)$. IR $(\mathrm{KBr}) v_{\max } / \mathrm{cm}^{-1}: 2958,2928,2870,1460,1376,1256,1193,736 \mathrm{~cm}^{-1}$. MS (EI) $\mathrm{m} / z(\%): 194.0(\mathrm{M}+, 100)$.

di-3-Methoxypropyl selenide (3b). Yellow oil , yield:92\%, $1040 \mathrm{mg},{ }^{1} \mathrm{HNMR}(300 \mathrm{MHz}$, $\left.\mathrm{CDCl}_{3}\right): \delta_{\mathrm{H}} 3.44\left(\mathrm{t}, J=6.2 \mathrm{~Hz}, 4 \mathrm{H}, \mathrm{CH}_{2} \mathrm{Se}\right), 3.33\left(\mathrm{~s}, 6 \mathrm{H}, \mathrm{CH}_{3} \mathrm{O}\right), 2.62\left(\mathrm{t}, J=7.2 \mathrm{~Hz}, 4 \mathrm{H}, \mathrm{OCH}_{2}\right), 1.97-$ $1.88\left(\mathrm{~m}, 4 \mathrm{H}, \mathrm{CH}_{2} \mathrm{CH}_{2} \mathrm{CH}_{2}\right) .{ }^{13} \mathrm{C}$ NMR $\delta \mathrm{c} 72.00,58.55,30.54,20.42$. IR $(\mathrm{KBr}) v_{\max } / \mathrm{cm}^{-1} 2978$, $1454,1383,1209,1117,860 \mathrm{~cm}^{-1}$; MS (EI) $\mathrm{m} / z$ (\%): $225.86(\mathrm{M}+, 17), 71.9(100)$.

di-Benzyl selenide (3c). ${ }^{16}$ Yellow solid, yield: $82 \%$, $1074 \mathrm{mg}$. Mp $45-46{ }^{\circ} \mathrm{C}$; ${ }^{1} \mathrm{H}-\mathrm{NMR}$ $\left(300 \mathrm{MHz}, \mathrm{CDCl}_{3}\right): \delta_{\mathrm{H}} 7.32-7.23(\mathrm{~m}, 10 \mathrm{H}, \mathrm{Ar}-\mathrm{H}), 3.74\left(\mathrm{~s}, 4 \mathrm{H}, \mathrm{CH}_{2}\right)$. IR $(\mathrm{KBr}) v_{\max } / \mathrm{cm}^{-1}: 3030$, 2916, 2847, 1600, 1493, 1076, 1028, 847,730 $\mathrm{cm}^{-1}$. MS (EI) $\mathrm{m} / \mathrm{z}$ (\%): $262.3(\mathrm{M}+, 47), 182$. 491.3(100).

di-Methybenzyl selenide (3d). ${ }^{10 \mathrm{c}}$ Yellow solid, yield 85\%, $1233 \mathrm{mg}, \mathrm{mp} 76-77{ }^{\circ} \mathrm{C} ;{ }^{1} \mathrm{H}-\mathrm{NMR}$ $\left(300 \mathrm{MHz}, \mathrm{CDCl}_{3}\right): \delta_{\mathrm{H}} 7.26-7.12(\mathrm{~m}, 8 \mathrm{H}, \mathrm{Ar}-\mathrm{H}), 3.74\left(\mathrm{~s}, 4 \mathrm{H}, \mathrm{CH}_{2}\right), 2.38\left(\mathrm{~s}, 6 \mathrm{H}, \mathrm{CH}_{3}\right) . \mathrm{IR}(\mathrm{KBr})$ $v_{\max } / \mathrm{cm}^{-1}: 3020,2919,1511,1415,1179,1020,817,715 \mathrm{~cm}-1$. MS (EI) $\mathrm{m} / z(\%): 290(\mathrm{M}+, 6)$, 104.87 (100).

di-(1,3-Dioxan-2-yl)methyl selenide (3e). Yellow oil, yield 79\%, $1003 \mathrm{mg} ;{ }^{1} \mathrm{H}-\mathrm{NMR}$ (300 $\left.\mathrm{MHz}, \mathrm{CDCl}_{3}\right): \delta_{\mathrm{H}} 3.43\left(\mathrm{t}, J=6.0 \mathrm{~Hz}, 4 \mathrm{H}, \mathrm{CH}_{2} \mathrm{Se}\right), 2.60(\mathrm{~d}, J=7.8 \mathrm{~Hz}, 2 \mathrm{H}, \mathrm{CH}), 2.01-1.85(\mathrm{~m}, 8 \mathrm{H}$, $\left.\mathrm{CH}_{2} \mathrm{CH}_{2}\right) .{ }^{13} \mathrm{C}$ NMR $\delta_{\mathrm{C}} 103.76,64.93,34.89,17.50$. IR $(\mathrm{KBr}) v_{\max } / \mathrm{cm}^{-1}: 2949,2882,1406$, $1129,1036,867 \mathrm{~cm}^{-1}$. MS (EI) $\mathrm{m} / z(\%): 254.0(\mathrm{M}+, 34), 171.9(100)$. 
di-Cyclohexyl selenide (3f). Yellow oil, yield: $92 \%, 1132 \mathrm{mg} ;{ }^{1} \mathrm{H}-\mathrm{NMR}\left(300 \mathrm{MHz}, \mathrm{CDCl}_{3}\right): \delta_{\mathrm{H}}$ 3.00-2.93(m, 2H, CHSe), 2.03-1.99 (m, 8H, $\left.\mathrm{CH}_{2} \mathrm{CHSe}\right), 1.76-1.34\left(\mathrm{~m}, 12 \mathrm{H}, \mathrm{CH}_{2}\right)$. IR $(\mathrm{KBr})$ $v_{\max } / \mathrm{cm}^{-1}: 2880,1453,1350,1258,997,889 \mathrm{~cm}^{-1}$. MS (EI) $\mathrm{m} / z(\%): 246.1(\mathrm{M}+, 30), 164.0(49)$, 83.1(100).

di-1,1-Ethylidene selenide $(\mathbf{3 g}) .{ }^{11 \mathrm{~b}}$ Yellow oil, yield $1059 \mathrm{mg}, 73 \% .{ }^{1} \mathrm{H}-\mathrm{NMR}: \delta_{\mathrm{H}} 7.35-7.31(\mathrm{~m}$, $10 \mathrm{H}, \mathrm{Ar}-\mathrm{H}), 4.09-3.92\left(\mathrm{~m}, 2 \mathrm{H}, \mathrm{CHCH}_{3}\right), 1.79-1.65$ (m, 6H, $\left.\mathrm{CHCH}_{3}\right)$. IR (KBr) $v_{\max } / \mathrm{cm}^{-1}: 3026$, 2959, 2862, 1600, 1492, 1452, 1372, 1083, 1023, 762, $696 \mathrm{~cm}^{-1}$. MS (EI) m/z (\%):289.9 (M+, 39), 183.8 (75), 76.8(100).

di-t-Butyl selenide (3h). ${ }^{\text {1e }}$ Yellow oil, yield 45\%, $437 \mathrm{mg} ;{ }^{1} \mathrm{H}-\mathrm{NMR}: \delta_{\mathrm{H}} 1.54\left(\mathrm{~s}, 18 \mathrm{H}, \mathrm{CH}_{3}\right) .{ }^{13} \mathrm{C}$ NMR $\left(\mathrm{CDCl}_{3}\right): \delta \mathrm{c}=43.4,35.2$. IR $(\mathrm{KBr}) v_{\max } / \mathrm{cm}^{-1}: 2974,2928,2891,1455,1383,1090,1050$, $881 \mathrm{~cm}^{-1}$. MS (EI) $\mathrm{m} / z(\%): 194.2\left(\mathrm{M}^{+}, 33\right), 138.2$ (63), 57.2 (100).

Diphenyl selenide(3i). ${ }^{8 d}$ Brownish yellow oil, yield: $96 \%, 1123 \mathrm{mg}$. Bp156- $157^{\circ} \mathrm{C} / 6 \mathrm{mmHg} .{ }^{1} \mathrm{H}-$ NMR $\left(\mathrm{CDCl}_{3}, 300 \mathrm{MHz}\right): \delta_{\mathrm{H}} 7.52-7.49(\mathrm{~m}, 4 \mathrm{H}, \mathrm{Ar}-\mathrm{H}), 7.31-7.28(\mathrm{~m}, 6 \mathrm{H}, \mathrm{Ar}-\mathrm{H})$. IR $(\mathrm{KBr})$ $v_{\max } / \mathrm{cm}^{-1}: 3058,1578,1477,1438,1023,734,690 \mathrm{~cm}^{-1}$. MS (EI) $\mathrm{m} / z$ (\%): $\left.234 \mathrm{M}+22\right), 157$ (100), 77 (90).

di-4-Tolyl selenide (3l). ${ }^{16}$ Yellow solid, yield: 98\%, $1284 \mathrm{mg}$, m.p. $66-68{ }^{\circ} \mathrm{C}$; ${ }^{1} \mathrm{H}$ NMR $\left(300 \mathrm{MHz}, \mathrm{CDCl}_{3}\right): \delta_{\mathrm{H}} 7.24-7.30(\mathrm{~m}, 4 \mathrm{H}, \mathrm{Ar}-\mathrm{H}), 7.07-7.12(\mathrm{~m}, 4 \mathrm{H}, \mathrm{Ar}-\mathrm{H}), 2.46\left(\mathrm{~s}, 6 \mathrm{H}, \mathrm{CH}_{3}\right)$. IR (KBr) $v_{\max } / \mathrm{cm}^{-1}: 3055,1488,1053,1008,803,737 \mathrm{~cm}^{-1}$. MS (EI) m/z (\%): 262.1 (M+, 100), 170.0((98), 91.1(96).

di-2-Tolyl selenide (3m). ${ }^{\mathbf{1 b}}$ Yellow solid, yield: 96\%, $1258 \mathrm{mg}, \mathrm{Mp}$ 60-61 ${ }^{\circ} \mathrm{C} .{ }^{1} \mathrm{H}$ NMR (300MHz, $\left.\mathrm{CDCl}_{3}\right): \delta_{\mathrm{H}} 7.27-7.17(\mathrm{~m}, 6 \mathrm{H}, \mathrm{Ar}-\mathrm{H}), 7.09-7.04(\mathrm{~m}, 2 \mathrm{H}, \mathrm{Ar}-\mathrm{H}), 2.46\left(\mathrm{~s}, 6 \mathrm{H}, \mathrm{CH}_{3}\right)$. IR (KBr) $v_{\max } / \mathrm{cm}^{-1}: 3057,1476,1069,735,690 \mathrm{~cm}^{-1}$. MS (EI) m/z (\%): 262.3 (M+, 48), 182.4(100), 91.3(36).

di-4-Methoxyphenyl selenide (3n). ${ }^{8 d}$ Yellow solid, yield: $98 \%, 1441 \mathrm{mg} . \mathrm{Mp} .57-58{ }^{\circ} \mathrm{C} ;{ }^{1} \mathrm{H}$ NMR: $\delta_{\mathrm{H}} 7.41(\mathrm{~d}, J=8.7 \mathrm{~Hz}, 4 \mathrm{H}, \mathrm{Ar}-\mathrm{H}), 6.81(\mathrm{~d}, J=8.7 \mathrm{~Hz}, 4 \mathrm{H} \mathrm{Ar}-\mathrm{H}),$,3.76 (s, 3H, OCH$)_{3}$. IR (KBr) $v_{\text {max }} / \mathrm{cm}^{-1}: 3055,1495,1473,1246,1030,748 \mathrm{~cm}^{-1}$. MS (EI) m/z (\%): 294 (M+, 30), 214(100), 107(10).

di-2-Methoxyphenyl selenide (3o). ${ }^{20}$ Yellow solid, yield: $96 \%, 1411 \mathrm{mg}, \mathrm{Mp} 51-52{ }^{\circ} \mathrm{C} ;{ }^{1} \mathrm{H}$ NMR (300MHz, CDCl $)_{3}$ ): $\delta_{\mathrm{H}} 7.56-7.53(\mathrm{~m}, 2 \mathrm{H}, \mathrm{Ar}-\mathrm{H}), 7.26-7.18$ (m, $\left.2 \mathrm{H}, \mathrm{Ar}-\mathrm{H}\right)$, 6.89-6.80 (m, $4 \mathrm{H}, \mathrm{Ar}-\mathrm{H}), 3.91\left(\mathrm{~s}, 6 \mathrm{H}, \mathrm{OCH}_{3}\right)$. IR (KBr) $v_{\max } / \mathrm{cm}^{-1}: 3055,1495,1473,1246,1030,748 \mathrm{~cm}^{-1} . \mathrm{MS}$ (EI) $\mathrm{m} / z$ (\%): $294.3(\mathrm{M}+, 100), 214.3(72), 77.3(40)$.

bis-(4-Dimethylaminophenyl) selenide (3p). Yellow solid, yield: 73\%, $1168 \mathrm{mg}$, Mp 119-120 ${ }^{\circ} \mathrm{C} ;{ }^{1} \mathrm{H}$ NMR $\left(300 \mathrm{MHz}, \mathrm{CDCl}_{3}\right): \delta_{\mathrm{H}} 7.48-7.25(\mathrm{~m}, 4 \mathrm{H}, \mathrm{Ar}-\mathrm{H}), 6.71-6.60(\mathrm{~m}, 4 \mathrm{H}, \mathrm{Ar}-\mathrm{H}), 2.95(\mathrm{~s}$, $\left.12 \mathrm{H}, \mathrm{N}\left(\mathrm{CH}_{3}\right)_{2}\right)$. IR (KBr) $v_{\max } / \mathrm{cm}^{-1}: v 3022,2809,1596,1503,1443,1364,1076,944,807 \mathrm{~cm}^{-}$ ${ }^{1} . \mathrm{MS}(\mathrm{EI}) \mathrm{m} / \mathrm{z}(\%): 319.9(\mathrm{M}+, 12), 239.9$ (100), 119.9(51), 76.9(16).

2-(2-Thienylseleno)thiophene (3q). Pale yellow oil, yield: $88 \%, 1082 \mathrm{mg} ;{ }^{1} \mathrm{H}$ NMR $(300 \mathrm{MHz}$, $\left.\mathrm{CDCl}_{3}\right): \delta_{\mathrm{H}}$ 7.49-7.35 (m, 2H, thiophene-H), 7.28-7.22 (m, 2H, thiophene-H), 6.93-7.02 $((\mathrm{m}, 2 \mathrm{H}$, thiophene-H). IR (KBr) $v_{\max } / \mathrm{cm}^{-1}: 3072,2912,1587,1397,1076,953,840 \mathrm{~cm}^{-1} . \mathrm{MS}(\mathrm{EI}) \mathrm{m} / \mathrm{z}$ (\%):246.1 (M+, 25), 166.2(100). 
di-1-Naphthyl selenide (3r). ${ }^{\mathbf{1 7}}$ Yellow liquid, yield: $90 \%, 1503 \mathrm{mg} ;{ }^{1} \mathrm{H}$ NMR: $\delta_{\mathrm{H}} 8.35-8.32(\mathrm{~m}$, 2H,naphthyl-H), 8.19 (d, 2H, J=8.1Hz, naphthyl-H), 7.88-7.78 (m, 4H, naphthyl-H), 7.547.47(m, 4H, naphthyl-H), $7.28\left(\mathrm{t}, 2 \mathrm{H}, J=7.2 \mathrm{~Hz}\right.$, naphthyl-H). IR $(\mathrm{KBr}) v_{\max } / \mathrm{cm}^{-1}: 3054,1561$, 1386, 1040, $769 \mathrm{~cm}^{-1}$. MS (EI) $\mathrm{m} / z$ (\%): $334.2(\mathrm{M}+, 46), 253.3$ (100), 126.3 (92), 77.2(30).

di-4- Chlorophenyl selenide (3s). ${ }^{17}$ Yellow solid, yield: $92 \%, 1389 \mathrm{mg}$, Mp 97-98 ${ }^{\circ} \mathrm{C} ;{ }^{1} \mathrm{H}$ NMR $\left(300 \mathrm{MHz}, \mathrm{CDCl}_{3}\right): \delta_{\mathrm{H}} 7.37$ (d, J=8.4Hz, 4H,Ar-H), 7.24 (d, J=8.1Hz, 4H, Ar-H).IR (KBr) $v_{\max } / \mathrm{cm}^{-1}: 3063, \quad 1472,1385, \quad 1088, \quad 1009, \quad 812 \quad 727 \mathrm{~cm}^{-1} . \mathrm{MS} \quad(\mathrm{EI}) \quad \mathrm{m} / \mathrm{z}(\%): \quad 302.0$ $(\mathrm{M}+, 32), 222.1(100), 152.1(33), 75.1(32)$.

di-3- Fluorophenyl selenide(3t). Yellow solid, yield: $71 \%, 959 \mathrm{mg}, \mathrm{Mp} 74-76{ }^{\circ} \mathrm{C} ;{ }^{1} \mathrm{H} \mathrm{NMR}: \delta_{\mathrm{H}}$ 7.37-7.42 (m, 2H, SeAr-H), 7.28-7.15 (m, 2H, FAr-H), 7.01-6.94 (m, 4H, Ar-H). ${ }^{13} \mathrm{C}$ NMR $\left(\mathrm{CDCl}_{3}, 300 \mathrm{MHz}\right) \delta_{\mathrm{C}} 161.36,130.92,128.84,120.26,115.15,114.87 . \mathrm{IR}(\mathrm{KBr}) v_{\max } / \mathrm{cm}^{-1}: 3062$, 1588, 1470, 1262, 1212, 1081, 1055,856, 776cm -1. MS (EI) m/z (\%): $269.8(\mathrm{M}+, 15)$, 174.5(100), 94.9(69), 74.9(56).

di-2, 4-Dimethylphenyl selenide (3u). Yellow solid, yield: $77 \%, 1117 \mathrm{mg}, \mathrm{Mp} 87-88{ }^{\circ} \mathrm{C}$; ${ }^{1} \mathrm{HNMR} \quad(300 \mathrm{MHz}, \mathrm{CDCl} 3): \quad \delta_{\mathrm{H}} 7.14-7.08(\mathrm{~m}, \quad 2 \mathrm{H}, \quad \mathrm{Ar}-\mathrm{H}), 6.89-6.87 \quad(\mathrm{~m}, \quad 4 \mathrm{H}, \quad \mathrm{Ar}-\mathrm{H})$, $2.40\left(\mathrm{~s}, 6 \mathrm{H}, \mathrm{CH}_{3}\right), 2.33\left(\mathrm{~s}, 6 \mathrm{H}, \mathrm{CH}_{3}\right) .{ }^{13} \mathrm{C} \mathrm{NMR}(\mathrm{CDCl} 3,300 \mathrm{MHz}) \delta_{\mathrm{C}} 139.82,137.51,133.38$, 131.32, 128.07, 127.75, 127.75, 122.54, 21.38. IR (KBr) $v_{\max } / \mathrm{cm}^{-1}: 3005,2968,2918,1600$, 1472, 1376, 1028, 873, 809 cm-1. MS (EI) m/z (\%): 289.9 (M+39), 183.8(71), 104.9(59), 76.9(100).

di-2, 6-Dimethylphenyl selenide (3v). ${ }^{2 \mathrm{~d}}$ Yellow solid, yield: $68 \%, 986 \mathrm{mg}, \mathrm{M} . \mathrm{p} .85-86{ }^{\circ} \mathrm{C} ;{ }^{1} \mathrm{H}$ NMR $\left(300 \mathrm{MHz}, \mathrm{CDCl}_{3}\right): \delta_{\mathrm{H}} 7.13-7.00(\mathrm{~m}, 6 \mathrm{H}, \mathrm{Ar}-\mathrm{H}), 2.30\left(\mathrm{~s}, 12 \mathrm{H}, \mathrm{CH}_{3}\right) . \mathrm{IR}(\mathrm{KBr}) v_{\max } / \mathrm{cm}^{-}$ ${ }^{1}: 3049,2950,2918,1455,1374,1161,1021,769,707 \mathrm{~cm}-1 . \mathrm{MS}(\mathrm{EI}) \mathrm{m} / \mathrm{z}(\%): 290(\mathrm{M}+24)$, 104.9 (100), 79.9 (16).

\section{Acknowledgements}

We are grateful to the Natural Science Found of China Guangdong Province (Grant Nos.039213) and National University Student Innovation Program (Grant No.101055920 and cx10067) for supporting this research.

\section{References}

1. (a) Huguet, L. J. Adv. Chem. Ser. 1967, 76, 345. (b) Sanjio, S. Z.; Snigdha, P.; Harkesh, B.; Gotthelf, W. Tetrahedron Lett. 2005, 46, 665. (c) Ouchi, A.; Liu, S.; Li, Z.; Kumar, S. A.; Suzuki, T.; Hyugano, T.; Kitahara, H. J. Org. Chem. 2007, 72, 8700. (d) Andrez, J. C. Beilstein J. Org. Chem. 2009, 5, 33.(e) Klapotke, T. M.; Krumm, B.; Scherr, M. Inorg. Chem. 2008, 47, 4712. 
2. (a) Wirth, T., Ed. Organoselenium Chemistry; Topics in Current Chemistry 208; SpringerVerlag: Heidelberg, 2000. (b) Nogueira, C. W.; Zeni, G..; Rocha, J. B. T. Chem. Rev.2004, 104, 6255. (c) Freudendahl, D. M.; Santoro, S.; Shahzad, S. A.; Santi, C.; Wirth, T. Angew. Chem., Int. Ed. 2009, 48, 8409. (d) Hisashi, F.; Hisatomo, M.; Naomiehi, F.Tetrahedron 1996, 52, 13951.

3. (a) Singh, D.; Deobald, A.M.; Camargo, L.R.S.; Tabarelli, G.; Rodrigues, O.E.D.; Braga, A. L. Org. Lett. 2010, 12, 3288. (b) Wang, J. X.; Cui, W.; Hu, Y. J. Chem. Soc., Perkin Trans. 1994, 2341. (c) Krief, A.; Derock, M. Tetrahedron Lett. 2003, 43, 3083. (d) Krief, A.;

Dumont, W.; Delmotte, C. Angew. Chem., Int. Ed. 2000, 39, 1669.

4. (a) Back, T. G.; Moussa, Z. J. Am. Chem. Soc. 2003, 125, 13455.(b) Geiger, P. G.; Lin, F.; Girotti, A. W. Free Radical Biol. Med. 1993, 14,251.

5. Klayman, D. L.; Griffin, T. S. J. Am. Chem. Soc. 1973, 95, 197.

6. Krief, A.; Derock, M. Tetrahedron Lett. 2002, 43, 3083.

7. Rossi, R. A.; Penenory, A. B. J. Org. Chem. 1981, 46, 4580.

8. (a) Reddy, V. P.; Kumar, A. V.; Swapna, K.; Rao, K. R. Org. Lett. 2009, 11, 951. (b) Saha, A.; Saha, D.; Ranu, B. C. Org. Biomol. Chem. 2009, 7, 1652. (c) Swapna, K.; Murthy, S.N.; Nageswar,Y. V. D. Eur. J. Org. Chem. 2011, 1940. (d) Alves, D.; Santos, C. V.; Soares, L. C.; Souza, D. D.; Rodrigues, O.E.D.; Braga, A. L. Tetrahedron Lett. 2009, 50, 6635.

9. (a) Ranu, B. C.; Mandal, T.; Samanta, S.Org. Lett., 2003,5,1399.(b) Ranu, B. C.; Mandal, T. J. Org. Chem. 2004, 69, 5793.(c) Munbunjong, W.; Lee, E. H.; Chavasiri , W.; Jang, D. K. Tetrahedron Lett. 2005.46, 8769.

10. (a) Taniguchi, N.; Onami, T. Synlett. 2003, 829. (b) Wang, L.; Wang, M.; Huang, F. Synlett. 2005, 2007. (c) Choudhury, J.; Sinha, P.; Prabhakar, S.; Vairamani, M.; Roy, S. Phosphorus, Sulfur, Silicon 2008, 183, 2943.

11. (a) Ranu, B. C.; Chattopadhyay, K.; Banerjee, S. J. Org. Chem. 2006, 71, 423. (b) Harpp, D.N.; Gingras, M. J. Am. Chem. Soc. 1988, 110, 7737.

12. Beletskaya, I. P.; Ananikov, V. P. Eur. J. Org. Chem. 2007, 21, 3431.

13. Zhao, X.; Yu, Z.; Yan, S.; Wu, S.; Liu, R.; He, W.; Wang, L. J. Org. Chem. 2005, 70, 7338.

14. Wang, Y. Li, H.; Chen, X. Li, T.; Zhao, D. Tetrahedron 2010, 66, 8583.

15. Khurana, J.M.; Sharma,V.; Chacko, S.A. Tetrahedron 2007, 63, 966.

16. Reddy, P. V.; Kumar, A. V.; Rao, K.R. J. Org. Chem. 2010, 75, 8720.

17. Kumar, A .V.; Reddy, V.P.; Reddy, C.S.; Rao, R.K. Tetrahedron Lett. 2011, 52, 3978.

18. Sada, M.; Matsubara, S. Tetrahedron 2011, 67, 2612.

19. Taniguchi, N.; Onami ,T. J. Org. Chem. 2004, 69, 915.

20. Rheinboldt, H.; Giesbrecht, E. Chem. Ber. 1955, 88, 1037. 